\title{
The Weight of Bodily Presence in Art and Liturgy
}

\author{
Hannah Lyn Venable (id
}

\section{check for}

updates

Citation: Venable, Hannah Lyn. 2021. The Weight of Bodily Presence in Art and Liturgy. Religions 12: 164. https://doi.org/10.3390/rel12030164

Academic Editor: Christina

M. Gschwandtner

Received: 2 February 2021

Accepted: 2 March 2021

Published: 3 March 2021

Publisher's Note: MDPI stays neutral with regard to jurisdictional claims in published maps and institutional affiliations.

Copyright: (C) 2021 by the author. Licensee MDPI, Basel, Switzerland. This article is an open access article distributed under the terms and conditions of the Creative Commons Attribution (CC BY) license (https:// creativecommons.org/licenses/by/ $4.0 /)$.
Department of Philosophy, Texas State University, San Marcos, TX 78666, USA; hannah.venable@gmail.com
Abstract: This essay addresses the question of virtual church, particularly on whether or not liturgy can be done virtually. We will approach our subject from a somewhat unusual perspective by looking to types of aesthetic experiences which we have been doing "virtually" for a long time. By exploring how we experience art in virtual and physical contexts, we gain insight into the corresponding experiences in liturgical practices. Drawing on Mikel Dufrenne, Maurice Merleau-Ponty and Gabriel Marcel, I first examine the importance of the body when we experience "presence" in aesthetic environments. Next, I consider the weight of the body in experiences of presence in liturgical practices, both in person and virtual, guided again by Gabriel Marcel as well as Bruce Ellis Benson, Emmanuel Falque, Christina Gschwandtner and Éric Palazzo. Through these reflections, I argue that what art teaches us about the significance of the physical closeness of the human applies to the practice of liturgy and that, while unexpected benefits will surface in virtual settings, nothing replaces the powerful experiences that arise when the body is physically present.

Keywords: art; liturgy; body; presence; church; virtual; aesthetics; digital

\section{Introduction}

No one will deny that there is a substantial difference between meeting in person and meeting virtually. Now, more than ever due to the covid crisis, we have experienced virtual gatherings in almost every sphere of our lives, prompting us to constantly evaluate the advantages and disadvantages to these virtual interactions. For religious gatherings, these types of discussions have been of critical importance, sometimes causing great tension and conflict between members of the same communities. This essay addresses the question of virtual church, particularly on whether or not liturgy can be done virtually. We will approach our subject from a somewhat unusual perspective by looking to types of aesthetic experiences which we have been doing "virtually" for a long time. By exploring how we experience art in virtual and physical contexts, we gain insight into the corresponding experiences in liturgical practices. Drawing on Mikel Dufrenne, Maurice Merleau-Ponty and Gabriel Marcel, I first examine the importance of the body when we experience "presence" in aesthetic environments. Next, I consider the weight of the body in experiences of presence in liturgical practices, both in person and virtual, guided again by Gabriel Marcel as well as Bruce Ellis Benson, Emmanuel Falque, Christina Gschwandtner and Éric Palazzo. Through these reflections, I argue that what art teaches us about the significance of the physical closeness of the human applies to the practice of liturgy and that, while unexpected benefits will surface in virtual settings, nothing replaces the powerful experiences that arise when the body is physically present.

When speaking of presence in relation to art and liturgy, I am referring to a specific kind of human experience that includes the full engagement, both mental and physical, of a person. We often think of presence in a broader sense: as a student, I may say the word "present" after my name is read off the class roster all the while knowing that my response has little bearing on whether or not I will actually be present during class and pay attention. In the context of a musical experience, Gabriel Marcel offers this helpful definition of presence: 
But what I call presence is the sudden emergence, unforeseeable, salvific, of a form that is not simply traced, but wedded, that is to say, re-created from within and in which an entire experience, instead of being lost, instead of being scattered like sand and dust, concentrates itself, affirms itself, proclaims itself. (Marcel 2005, p. 113)

Presence, in this narrower sense, is an immediate, unexplainable experience of something that recreates or refreshes itself in a such way as to make it known to us. Rather than a jumble of sensations, presence unites the experience into a cohesive whole that brings it meaning. The feeling of presence is often sudden and unexpected due to the tearing down of boundaries between us and the thing (whether it is an actual object, person or place). As we will see, we do not have to be in the same place or at the same time as something in order to experience presence. Furthermore, we can be physically in a place, but not in fact present, such as being in class but not paying attention. "Bodily presence", then, is where one is both physically in a specific place and time and fully engaged in the experience. Although we will discuss presence in multiple forms, it is this type of presence, where we are fully involved in something and physically there, that we are most interested in for this essay.

This type of presence points to an understanding of the human as an embodied creature, a being that cannot be reduced to false dichotomies between mind and body, the physical and the mental. Maurice Merleau-Ponty writes that we need "to treat the human subject as an indivisible consciousness [une conscience indécomposable] that is wholly present in each of its manifestations" (Merleau-Ponty 2012, p. 122; French: Merleau-Ponty 1945, p. 152). The word indécomposable illustrates how the human is something that cannot be divided into parts, broken down, taken apart or separated. The manifestations of the body directly reveal the intentions of the consciousness, making the body not a shell for the mind, but an attestation to the unity of the human. ${ }^{1}$ In examining human experience, it is still helpful to use certain descriptions such as how an experience is bodily or how it engages the mind. In fact, it is through exploring these kinds of distinctions in art and liturgy that we become aware of the complexity of human experience and the ways that the mental and bodily aspects are woven together in the human as a concrete whole.

\section{Presence in Art}

For those in the phenomenological and existentialist traditions, art does more than reflect aspects of life that are already there: art makes up part of the human life. Creating and participating in art does not merely mirror our other human experiences but also creates and shapes human life in a unique way. As a result, phenomenologists often turn to art for clarification on how humans encounter and interact with the world. Joseph D. Parry and Mark Wrathall describe the intricate link between art and phenomenology: "For the existential phenomenologists, art is a neighbor to and co-worker with philosophy, and both art and philosophy proceed by directing our attention to our experience of the world ... art can show us what philosophy, especially phenomenology, should look like" (Parry and Wrathall 2011, p. 2). Martin Heidegger illustrates this by calling philosophers to practice "poetic thinking", which approaches the world as a place of deep mystery and meaning, as opposed to "technological thinking", which reduces the world to a set of facts (Heidegger 2008, pp. 340-41). This is not to replace philosophy with poetry, but to show that the language of poetry uncovers truth in a way that philosophy should emulate; for, "the nature of poetry", Heidegger writes, "is the founding of truth" (Heidegger 1976, p. 697).

Both art and phenomenology lead us to truth by giving a voice to the world around us; the world is already there, but its true character is made or founded through these disciplines. We can call this task the "founding of truth" or the "founding of being",

1 For further discussion on the human as an indivisible consciousness, please see chapter two of my upcoming book (Venable 2021). 
because it begins breathing life into the truth and reality of the world. ${ }^{2}$ In the preface to the Phenomenology of Perception, Merleau-Ponty writes of this shared goal for art and phenomenology: "The phenomenological world is not the making explicit of a prior being, but rather the founding of being; philosophy is not the reflection of a prior truth, but rather, like art, the actualization of a truth" (Merleau-Ponty 2012, p. lxxxiv). Phenomenology does not perform an analysis on what has been, but it is an engagement in what is now. A sorrowful tune, for example, actualizes the truth of human sadness in a way different from a written analysis, because art expresses human life as it is experienced in the moment. Art teaches phenomenology how to grasp life as it is experienced immediately, prior to analysis and reflection.

One way that art shapes human life is by making objects, places and people present to us. Mikel Dufrenne, in his deep analysis of aesthetic experience, writes that "things are present to us in perception, and there is no screen between them and us" (Dufrenne 1973, pp. 336-37, italics his). We can use Dufrenne's distinction between a "work of art" and an "aesthetic object" to illustrate the intimacy found in presence. A work of art is the actual object that can be noticed without seeing its aesthetic qualities, but an aesthetic object is when that object is "the work of art perceived as a work of art" (lii, italics his). ${ }^{3}$ It is only when I perceive the work of art as an aesthetic object that I can experience presence. Strolling in a park, I see a sculpture in my path; if I see it only as an object to avoid and walk around, then it remains a work of art. However, if I stop to appreciate its aesthetic qualities, I perceive it as an aesthetic object feeling the presence of the sculpture and the meaning it conveys.

By its very nature, art allows us to feel the presence of something without it actually being physically in front of us. For the sake of this essay, we will consider these experiences of art as "virtual experiences" because of how art can reveal the reality of something to us that is not necessarily in our spatial reality. By "virtual", we do not always mean something presented on a computer screen, which is the technical definition, nor do we mean experiences of virtual reality, but rather we are thinking of anything that points to something not in our spatial or temporal reality. I have chosen the word "virtual" because of its applicability to our conversation about liturgy. In everyday speech, we usually refer to an online church event as a "virtual" event and thus, this article will follow that language. However, my use of "virtual" needs to be distinguished from two others. First, there is a genre of art called "virtual art" which includes certain types of digital art, virtual reality art and other technological creations of art (Popper 2006). When I talk about the way art provides a virtual experience, I am not referring to this specific genre. Second, "virtuality" is an idea drawn out of Bergson's philosophy that is developed by Gilles Deleuze as a new metaphysical notion of possibility (Deleuze 1990). The connections between this philosophical concept and changing technologies have been discussed elsewhere (Grimshaw 2014), but here we will focus on the connections between the virtual, as in something that cuts across spatial and temporal limits, and art so that we can apply it to the connections between the virtual, as in a digitally mediated experience, and religious rituals.

According to this nuanced view of "virtual", there are two ways that art provides virtual experiences. First, the work of art itself may be telling us something about the world that may or may not be physically present, such as a poem about love or a painting of a historical event. Neither love nor the historical event are materially there, and yet, as a spectator we may feel the reality of them in a fresh way. In this sense, there will almost always be a "virtual" element to art, because of how art points to ideas, objects, people

2 Heidegger writes that in each mode of founding, there is a "mode of preserving" meaning that in each establishment of truth, there is not something completely new as it is always based on the keeping or guarding of a truth already present (Heidegger 1976, p. 697). Following Heidegger, Merleau-Ponty is most likely thinking of the "founding of being" in a similar way.

3 This essay uses the phrase "aesthetic experience" over "artistic experience" to follow Dufrenne's notion that an aesthetic object is one that is perceived and experienced by a person. 
and places beyond itself. ${ }^{4}$ A second way that art can be seen as "virtual" is when we are experiencing a "copy" of the art, such as watching a recording of a symphony or seeing an online photo of a painting. Here not only is the work of art pointing to something not physically present, but the object itself, the recording or photo, is a virtual representation of the actual work of art.

A poem describing a beautiful rose illustrates the first way that an object can be present to us virtually through art. Marcel writes, "A rose in a poem can be something that is present to us in this way, but not, in most cases, a rose in a seedsman's catalogue" (Marcel 2001, p. 208). In contrast to an inventory or a scientific account, a poem has a way of reflecting on the beauty of a rose and allowing us to experience its presence without a single rose actually being there. Thomas Anderson, in his commentary on Marcel's The Mystery of Being, eloquently elucidates this passage:

The poem, through its words, is somehow able to help me become open and receptive to the reality of the rose itself and appreciate and welcome it just as the beautiful flower that it is ... the rose is a presence ... the rose affects me internally, for example, it may refresh me by its beauty, it may help me realize that nonhuman things can be intrinsically valuable, it may prompt me to care more for the natural world. (Anderson 2006, p. 93)

The poem is not a mere acknowledgment that roses exist somewhere in the world, but it recreates a rose in such a way that it inwardly transforms me. I am actually changed as a person by experiencing the rose as presented to me in the poem. This inward change points to a further step in aesthetic experience where we desire to create our lives as works of art. Reflecting on the creation of art makes us consider the creation of our own lives and pushes us to shape them into something beautiful.

Art can be virtual in the second way when we experience a copy of the actual work of art. ${ }^{5}$ Viewing an online photo of Cézanne's Mont Sainte-Victoire gives me the possibility to experience the presence of the painting, even though the actual painting is at the Musée $\mathrm{d}^{\prime}$ Orsay in Paris, and the possibility to feel the presence of the beautiful mountain of Mont Sainte-Victoire, even though the mountain stands miles away in the south of France. Cézanne's rendering of the scene might even enable me to observe aspects of the mountain landscape that I would not notice in person due to his multi-dimensional style of painting. Merleau-Ponty comments on Cézanne's art: "[Cézanne] did not want to separate the stable things which we see and the shifting way in which they appear; he wanted to depict matter as it takes on form, the birth of order through spontaneous organization ... Cézanne wanted to paint this primordial world" (Merleau-Ponty 1964, p. 13). A painting can reveal how I intuitively grasp the environment around me without pausing to reflect, how I am instantly connected to the world due to my primordial relation to it. We can be brought close to the world through art, even when the painting and the place of the painting is not physically in front of us, because art has a way of standing in the gap between the world and us, facilitating an experience of its presence in a new way such that it internally impacts us.

By transforming us in this unique way through presence, aesthetic experience does not seem bound by certain limits of space. Merleau-Ponty describes the way art feels beyond space when he wonders about the "real" location of a painting: "I would be at great pains to say where is the painting I am looking at it. For I do not look at it as I do at a thing; I do not fix it in its place. My gaze wanders in it as in the halos of Being. It is more accurate to say that I see according to it, or with it, than I see it" (Merleau-Ponty 2004, p. 296, italics his). Because art acts as a founding of being - a life-giver to the reality around us-a painting leads us beyond the material canvas and colorful paints to deeper meanings of the world.

4 One could imagine a situation where the work of art is placed in the location of what it represents. This would be something like placing a painting of a landscape on the land where the landscape was created. But even in this situation, the painting only captures one part of the scene, asking us to focus on it from that perspective.

5 Although we do not have the space to discuss it here, this will relate to the Plato's idea of art being three times removed from truth in Book $X$ of The Republic. Often taken as a negative view on art, it can be argued that it is positive in that art can still point us to truth in its own way (Plato 1976 , pp. 30-45). 
If art already manifests the presence of something such as a rose or a mountain in a virtual way, does the spatial presence of the body make a difference to our aesthetic experience? Furthermore, there is a sense in which aesthetic experience can feel beyond certain time constraints as well, such as when we feel pulled into a historical event through a painting or are grieved by a tragedy expressed in music from a long time ago. If aesthetic experience can be described as beyond space and time to a certain degree, we might conclude that the physical location of the body is not important. ${ }^{6}$

Even though art allows us to experience presence non-spatially and non-temporally, we cannot say that the role of the body is irrelevant. Attending a live symphony or ballet or viewing artwork at a museum are examples where the body has spatial closeness to the work of art and we can often attest to the powerful effects from these "less virtual" experiences of art. For example, discovering a beloved painting in a museum for the first time after only seeing photos of it online brings a whole new love and perspective to it. Most people would confirm that nothing quite compares to the energy that comes from live music-whether it be a rock concert, an orchestra or a musical. While presence can be experienced in many ways through art, there appears to be another level of presence that can be reached when the body is in the same physical space as the work of art. This is not to say that this deeper experience will always take place in these settings as we can be spatially in a place but not fully engaged in it, such as physically being at a theatre but remaining "inattentive" to the play (Dufrenne 1973, p. lii). Nevertheless, we can conclude that there is the possibility for a deeper engagement with presence when the body is physically present as well.

Additionally, however, it should be noted that all aesthetic experiences are to a certain extent bodily experiences, because whether we are seeing a painting with our eyes at a museum or on a website or whether we are listening to music at a concert hall or at home, we can never escape the body. In virtual settings, we may be less aware of our body, but it is still the way we access these experiences. Dufrenne articulates how experiences of art in different mediums all rely on the body:

[P]erception does begin in presence, and it is precisely aesthetic experience which confirms this ... Thus, the aesthetic object first manifests itself to the body, immediately inviting the body to join forces with it ... It is primarily our body that is moved by rhythm and that resonates with harmony. It is through the body that the aesthetic object is first taken up... And it is also through the body that there is a unity of the aesthetic object, especially in the case of composite works, such as opera or ballet... It is for the body that unity is given before diversity. (Dufrenne 1973, p. 339)

When we perceive a work of art, whether through feeling the beat of the music or seeing the colors of a painting, we take up these initial sensations in our body. Furthermore, it is through the body that we can make sense of them; prior to reflection, we recognize the aesthetic object as a united whole, putting together the colors to make one painting or connecting the scenes of the ballet into a story. After reflection, we will be able to articulate the parts of the aesthetic object that make up this whole, but it is the body which gives the sense of it first. Dufrenne concludes with: "Therefore, the presence of the aesthetic object to the body is necessary" (Dufrenne 1973, p. 341). In every circumstance, the body plays a necessary role in our experience of art and we cannot speak of an experience of art that is not, first and foremost, bodily. Recognizing the importance of the body in artistic presence teaches us that we cannot ignore the alterations that will take place when the aesthetic object is further removed from the body. Yes, all artistic experiences are bodily, but the more engaged the body is in the art the more we will be able to experience it.

This deeper experience of presence can be seen in the way the presence of self and the presence of others is felt during these less virtual aesthetic experiences. When the body is immersed in an aesthetic experience, deeper reflections on the self can take place, such as

Certainly, experiences are never fully beyond space and time as we are always in a certain time and at a certain place. But these descriptions help us capture the way that art can make us feel like we are being drawn out of our surrounding environment. 
unearthing hidden desires, confirming life decisions or bringing to mind old memories. This fosters the feeling of "being at home" in the world because "my body necessarily seems the symbol or materialized nucleus" (Marcel 2002, p. 92, italics his). Seeing how my body acts as the central place connecting the artwork and the self, I am able to identify myself with my body, valuing it as essential to who I am. A stronger connection with another person, who is there with us participating in the art, is another benefit to less virtual aesthetic experiences. Marcel writes that art can provide an "intermediary given" between myself and the other drawing us closer through the shared experience: "this intermediary given is for a concrete $u s$; it is an open communion of selves, the kind that is formed around a work that is intimately loved" (Marcel 1963, p. 68, italics his). The feeling of a "concrete us" can take place through the discovery of both of us loving the same novel or painting, but it also can happen in an even profounder way when I am with another person enjoying a work of art together in the same space and time.

In summary, this investigation of presence in aesthetic experience reveals the unique capacity of the human to feel the presence of something beyond the constraints of space and time. Neither the actual object that the art refers to, whether it be an idea, person or place nor the actual artwork, whether it be the original painting or a live concert, needs to be physically there in order for the art to change us internally and give us a new perspective on the world. In addition, though, we also found that because humans are bodily creatures, there are things gained by having bodily presence in aesthetic experiences such as a deeper sense of self and a singular connection to another person. Since art is necessarily experienced through the body, we see the deep value in aesthetic experiences that integrate the full physical presence of the body.

\section{Presence in Liturgy}

Turning now to liturgy, we will investigate the weight of bodily presence in liturgical experiences. ${ }^{7}$ Thinking of liturgy in broad terms as "the logic that governs the encounter between the human and God", as Jean-Yves Lacoste defines it, allows us to apply it to many areas of human life (Lacoste 2004, p. 2). While we generally refer to liturgy as the logic or order of a religious service, we must also consider liturgy as what takes place in our personal interactions with God. Charles Price and Louis Weil define intensive liturgy as "when Christians assemble to worship God" while extensive liturgy as "when Christians leave the assembly to conduct their daily affairs" and contend that these two forms of liturgy are "mutually dependent" (Price and Weil 2000, p. 207). Considering liturgy as both what happens in worship gatherings (intensive) and in daily life (extensive), we will now discuss three aspects of liturgy to understand the role of presence in its practices: liturgy as art, liturgy as bodily, and liturgy as communal. I will apply this three-part understanding to virtual and non-virtual experiences and argue that a full experience of liturgy must include the bodily presence of the self and others. ${ }^{8}$

\subsection{Liturgy as Art}

In the Jewish and Christian traditions, connections between art and liturgy can be traced back to the beginning of liturgical practices in the Hebrew Bible. During the exodus, for example, God directs the Israelites to create art according to certain guidelines so that they could properly worship. While wandering in the desert, God gave them careful instructions on the types of fabric for the curtains and the types of wood for the altar that they were to use for the construction of the tabernacle (Exodus 26). Éric Palazzo, in his study on art and liturgy in the Middle Ages, shows the essential connection between art and liturgy and writes that for many medieval theologians: "liturgy was by its very nature a 'synthesis of the arts,' where all the senses are appealed to" (Palazzo 2010, p. 27). Leaving

Many of the authors quoted in this section speak in terms of Christian liturgy and the examples come primarily from that tradition, but I believe that the insights in this essay can be applied to many faith traditions.

8 This discussion fits into the wider conversation about the proper relation between the church and technology as a whole. I will focus particularly on the technology involved in a virtual church experience here, but see (Berger 2017) and (Heidebrecht 2014) for a fuller discussion. 
the sensory aspect for the next section, these brief points gesture to art as the root of liturgy in ancient and medieval times. ${ }^{9}$

Reviewing historical as well as present-day liturgical practices, Bruce Ellis Benson's Liturgy as a Way of Life: Embodying the Arts in Christian Worship demonstrates that liturgy, including both extensive and intensive liturgy, is "strongly connected to the arts" (Benson 2013, p. 134). "Intensive liturgy", Benson argues, "is infused with artistic elements at every turn" (Benson 2013, p. 134). Artistic elements-such as singing, displaying artwork, placing the altar, and dancing - act as icons because they are valuable as "an aid to worship" and as a way of "directing us to the holy" (Benson 2013, p. 134). Extensive liturgy also relies on artistic elements, but it is done on the level of the individual: the person draws on art to shape one's soul (Benson 2013, p. 133). Just as participating in art prompts us to shape our lives as works of art so participating in liturgy helps us shape our souls into something beautiful and honoring to God. Romano Guardini writes that this is one of the primary purposes of liturgy: "The practice of the liturgy means that by the help of grace, under the guidance of the Church, we grow into living works of art before God, with no other aim or purpose than that of living and existing in His sight" (Guardini 1998, p. 71). Liturgy contains an internal artistic motivation that prompts us to make ourselves as works of art, living and breathing before the face of God.

Understanding liturgy as art tells us that liturgy also has the unique ability to make things present to us. Like art removing boundaries between something and the human, presence in liturgy also breaks down barriers, making something known to us in a new way so that we are internally transformed. Liturgy is designed to facilitate presence in many different ways and of many different things including places, such as a holy site; objects, such as the bread and wine of the eucharist; people, such as fellow worshippers, both living and dead; and, most critically for the believer, God. As with art, experiencing presence can transcend the boundaries of space and time giving us at the least the possibility of presence even in virtual liturgy.

\subsection{Liturgy as Bodily}

Before exploring the possibilities of virtual liturgy, we need to look at another key aspect of liturgy that is shared with art: liturgy as bodily. Just as we always experience art, whether virtual or not, as a bodily creature, liturgy is also designed with only a bodily creature in mind. In the establishment of liturgy in the Hebrew Bible, there appears to be a strong emphasis on the treatment and care of the body in relation to worship. A bronze basin, for example, was made and placed outside the tabernacle so that the priests could wash their hands and feet before entering (Exodus 30:17-21). On the Day of Atonement each year, the chosen priest must fully wash himself before entering the Holy of Holies (Leviticus 16:4). Each priestly article of clothing and outward adornment was carefully stipulated and constructed (Exodus 28; 39:1-31). Not only did the priests need to follow certain clothing and washing guidelines, but the people were also supposed to care for their bodies appropriately and could not enter the tabernacle or temple if they were sick or had some kind of bodily discharge. If someone was recovering from a skin disease, for example, there was a cleansing process of the body before the person could return to the camp and enter the tabernacle (Leviticus 14:1-32).

In contrast to the Jewish religious practices, some see the early church as placing less significance on the body in liturgy. However, this view seems to arise from a misguided Platonic interpretation of Christianity, which still made its way into the church from time to time, but cannot be justified by its core practices and texts. As Emmanuel Falque argues, the Christian understanding of the body, guided by St. Paul's admonitions, does not dismiss the body, but sees it as the "site of relation with and openness to God". The body becomes essential for the Christian life because it is the mode by which both the "the flesh (sarx) and the spirit (pneuma)" can receive God (Falque 2012, p. 55). This can be seen in

\footnotetext{
9 For further elaboration on art in liturgy, especially in relation to the body, see (Senn 2016, pp. 257-90).
} 
the many passages of Paul which speak about the proper use of the body in intensive and extensive liturgy. In intensive liturgy, for example, Paul rebukes the believers at Corinth for getting drunk from the wine and overeating the bread during communion (1 Corinthians 11:17-34). ${ }^{10}$ In living out the faith in extensive liturgy, believers must not use their bodies to engage in sexual immorality, because their bodies are temples of God (1 Corinthians 6:12-20).

Continuing to the medieval church, both in the west and the east, there remain strong "'sensory' aspects of ritual practice", as Palazzo demonstrates in his historical study (Palazzo 2008, p. 475). Palazzo writes, "The ritual of the medieval church is multidimensional and, alongside the importance it places on 'words' in the extended sense, it also accords enormous significance to places, persons and objects (books included!), to music, to aromas, and indeed to light and, in a general way, to images" (Palazzo 2008, p. 474). Each dimension of the liturgy, including words, art, smells and lighting, plays a role because each one draws a person toward God in a different way: "the liturgy appeals to all the senses as a way to allow humankind to meet God" (Palazzo 2010, p. 29). For Palazzo, the liturgical manuscript book serves "as a 'sacred space'", drawing on all five senses (Palazzo 2010, p. 48). One might not think that a book could engage all five senses, but a liturgical manuscript book is designed uniquely just for that. First, there are the visual and auditory senses which are represented in the "interplay of colors" such as between the gold words that are read aloud which are on top of the purple background. There is also the tactile sense in the feeling of the "texture of the parchment" and the raised "colors painted there" and the olfactory sense as the text would be incensed prior to the reading (Palazzo 2010, pp. 44-45). While taste was not in the book itself, the reading of the gospel text precedes the eating of bread, as the body of Jesus, considered the Word of God. The central place of this type of manuscript in the service demonstrates the importance of senses in medieval worship.

Today, while not all churches will place the same significance on the sensual elements of the liturgy as in the past, there are still many creative ways of including the senses in the church service. For example, one church asks the congregation to join hands as they sing their final song of the service as a physical reminder of how the church functions as a family. In his study on modern day churches, Benson observed many diverse services and writes that liturgical practices are "heavily dependent upon the senses—not just the mind-and thus the arts" (Benson 2013, p. 134). Benson writes this both as an observation and a prescription, calling many churches to recognize the importance of the sensual and artistic aspects of liturgy.

The continual incorporation of sensory aspects into liturgy is not just due to following the rules given by the Biblical text and church tradition, but is also driven by the underlying belief that full-bodied experiences actually draw a person closer to God. Inspired by $\mathrm{H}$. Urs von Balthasar, Falque writes of how the five senses enable us to experience God:

Thus I can perceive God in a way that is partly through the senses today... I see the beauty of God in my 'brother'; I am brought to understand the 'Word of God' through its message; I taste the kindness of God in the 'Eucharist'; through 'incense' God inspires my heart, and by 'prayer' he brings me to touch him or embrace him lovingly. (Falque 2012, p. 150)

From this, we can see how our senses allow us to perceive God both actually and metaphorically. Our actual sensual experiences of seeing, listening, tasting, smelling and touching in a liturgy bring us to God, because it links the physical aspects to the spiritual experiences of perceiving God, understanding God's Word, tasting God, being filled with God's Spirit and touching God. Our experience through the senses not only physically connects us to God, but also gives us a metaphor for experiencing the spiritual; we know

10 Paul may also be calling people out for coming drunk to the gathering. Also, while bread and wine were often part of the early communion ritual, there were many variations to this meal in the early church (McGowan 1999). 
what it is like to be touched physically by someone, so we can also grasp the feeling of being spiritually touched by God.

It is not that we only experience God through our senses, but it is only through having sensual experiences that we can access God. ${ }^{11}$ In his study on embodied liturgy, Frank Senn writes, "By what other means do we worship God than with our bodies? ... I believe that the renewal of worship requires a return to the body as the vehicle of worship" (Senn 2016, p. x). ${ }^{12}$ Returning to the body helps us engage deeply with liturgy because we are embracing our primary way of relating to God. We must never forget that we are bodily creatures: "one does not partake in the liturgy as a disembodied mind, but as a fully embodied person", states Benson (Benson 2013, p. 136). Liturgy teaches us to enjoy the beauty of our finitude, as fully embodied creatures, because it is in our finitude that we are drawn to spiritual realities that transcend the limits of space and time.

It is through the integration of our bodies, which experience the senses, and our minds, which reflect on these experiences, that we can fully engage in worship. Benson writes, "Our worship is not just for our souls but also for our bodies. It is designed to engage us both mentally and by way of our senses, with each reinforcing the other" (Benson 2013, p. 135). Thus, we can see that liturgy, both historically and by its very definition, is a bodily practice, as Christina Gschwandtner writes: "Liturgy is not just about eucharistic participation, but it is a fully embodied experience that engages the whole human being in a meaningful world" (Gschwandtner 2020, p. 28). Liturgy remains bodily because it acknowledges the human as an indivisible consciousness, a unity of mind and the body. This leads us to reflect on the level of bodily involvement in virtual and non-virtual liturgical practices, as we will discuss in our final section.

\subsection{Liturgy as Communal}

However, first, we must consider one final aspect of liturgy that will help us in this study: the place of community. This can be an easy one to overlook, because art and liturgy do not relate to community in the same way. Aesthetic experience certainly can include a communal aspect and can connect us in a powerful way to another person as a "concrete us", as Marcel says (Marcel 1963, p. 68). However, this is not the only way to experience art: art can also bring about presence when one is alone. In the case of liturgy, however, its very essence is communal and it cannot be a liturgy without a community as seen in the meaning of the word itself. Although there many connections between the Greek understandings of liturgy and the arts, such as those of music (mousike $\bar{e}$ ) and discipline (askēsis), liturgy (leitourgia) is unique, argues Benson, in that it includes a "service both to God and to our neighbors" showing the "communal nature of this work" (Benson 2013, p. 133). The communal nature comes from the roots of the word, leitourgia, which means the work (ergon) of the people (leitos). Proper liturgy is seen when people are gathered together for one purpose in order to work toward a united goal.

The linguistic roots of liturgy point to it being a communal act, as Gschwandtner writes: "Liturgy is plural and is experienced in its communal nature. Liturgy's goal ostensibly is to make its participants part of a body, to bring them together into a whole that is larger than a mere compilation of individuals" (Gschwandtner 2020, p. 146). In fact, some traditions even prohibit priests from celebrating a liturgy when there is no one there, because it would no longer be a liturgy! (Gschwandtner 2020, p. 147) Our participation in liturgy means that we are part of something larger than ourselves; we are part of the "liturgical entity", as Guardini writes, which "consists rather of the united body of the faithful as such - the Church-a body which infinitely outnumbers the mere congregation" (Guardini 1998, p. 19). This community not only includes those who are worshipping all across the world right now, but also includes the communion of all saints, even those who have already gone before us. We are united with them in this same world, while living

11 This is not to say that we must have all of our senses working properly in order to access God. Even when some of our senses are lost or disabled, we still have our other actual senses and our spiritual senses that will draw us, sometimes in very special ways, to God.

12 I would protest against the word "vehicle" in reference to the body, however, as this can imply a dualistic separation between the mind and the body. 
in the world according to different modes. Falque explains, "The communion of saints in Christianity (communion sanctorum) requires that we live in the same world - that of God, in which we are all included-although in different modes (earthly and heavenly) and with different forms of dazzlement (reflection in a mirror and transparence face to face)" (Falque 2012, p. 111). Although the way of being in the world may vary in the liturgical entity, we are connected together across space and across time in the worship of God. Thus, even when we may be worshipping alone, we are not actually alone, but with an invisible God and with the heavenly saints.

To summarize these three aspects of liturgy, we have seen how liturgy as art draws us into worshipping and into shaping our souls, how liturgy engages all five senses of the body and how liturgy lives only in communal settings. Speaking to the last two aspects, Gschwandtner writes, "[Liturgy] is designed for crowds, invites us to come and see and hear and taste and smell" (Gschwandtner 2020, p. 160). Liturgy is structured for the those called together to experience God and each other through our corporeal senses. Just the word "crowds" strikes a chord of fear in us during this covid crisis and brings us back to the critical questions for this project: How necessary are the "crowds" to the performance of liturgy? Can we still have a full liturgy without all five senses being engaged?

\subsection{The Case for Bodily Presence}

With these three dimensions in mind, we must now examine whether bodily presence is a necessary part of liturgy. Insisting on bodily presence in liturgy does not fit with some more expansive notions of liturgy, as advocated by Teresa Berger:

I am committed to an understanding of liturgy as a multi-textured practice, in which not only bodies, voices, and texts but also spaces, images, acoustics, and yes, pixels and internet-accessing devices play a role. Furthermore, my own understanding of liturgical practices is expansive, encompassing not only regular, public worship in brickand-mortar sanctuaries but also individual times of prayer... popular devotions, and digitally mediated worship practices. (Berger 2017, p. 11)

Berger is certainly right that spiritual experiences take place through many different mediums and in many different forms and we should not ignore the ways that we can still experience presence through them. Nevertheless, by expanding the definition of liturgy in this way, are we losing some of its essence? To address this problem of expansive liturgy especially in phenomenological literature, Gschwandtner suggests several attributes of liturgy that make it unique and that help distinguish it from the rest of life (Gschwandtner 2020, pp. 194-96). One unique aspect is that liturgy is something that is done physically in a place at a specific time: liturgy "thus provides a space and time deliberately and intentionally set aside for instantiating and practicing a certain way of being" (p. 195). Given the priority that is placed on bodily and communal aspects of liturgy as we have discussed, it seems right that a full liturgy will be performed at a deliberate place and time in order to include both of these aspects. By reflecting on virtual and non-virtual practices, I will argue that, while still providing many spiritual benefits, virtual liturgy ultimately falls short in obtaining a full liturgy, especially for practices in intensive liturgy.

Thinking of the virtual first, there are many aspects of a church service that can be done virtually to a certain extent, such as praying, reading, singing and preaching. Prayer spiritually connects us to people in faraway places and, for some believers, to people who have already passed away. Although I may not be physically with a friend going through a rough time, praying with her over the phone or through video chat, for example, can make her feel present to me and allow me to help carry her burden in spirit. Guided prayer can also be experienced virtually, through a prayer app, where one follows the prompts of the pastor or priest while being in the comfort of one's own home. Through prayer of any form, we can experience the presence of God, who is not bound by space or time and who is with us in the highest places of the heavens and in the deepest beds of the earth (Psalm 139:8). To even speak of virtual or non-virtual experiences of God seems nonsensical to believers because of God's attribute of omnipresence. 
The reading of the Biblical text also transcends physical and temporal limits. Like a poem that gives us a beautiful rose and a respect for true beauty, listening to a Bible passage or singing along with a song, even when it is recorded, can make a story or truth come alive to us in a new way. Replaying a recorded song over and over again typifies the element of repetition often present in liturgy. ${ }^{13}$ In so doing, the singing of the same truths can allow their meaning to sink deeper into the heart. Listening to a recorded sermon offers flexibility as we can pause the recording and take the time to write down a thought or pray about an idea before continuing with the next points.

As we think through these examples, we may ask whether or not virtual liturgical practices are reproducing pre-existing forms of liturgy or creating new forms, new ways of worship. ${ }^{14}$ Think again about the example of listening to a recorded sermon: here we have an existing form of liturgy, the preaching of the word, that can be experienced in a different way by the ability to listen when convenient and pause when needed. Or consider an app used for guided prayer, where one is led through a prayer by a person who is not physically there at one's home. In both of these examples, it seems that these digital practices are not creating something new, but performing old practices, preaching and prayer, in an altered way. In her study of digital liturgy, Berger argues that these new practices "do not represent a radical revolution but rather a reconfiguration of existing practices" (Berger 2017, p. xii). In remaking these practices, we may discover new tools to facilitate our worship and new perspectives on our religious beliefs. Berger writes that "being @ worship", by which she means worshipping through digital mediation, "call[s] forth new ways of attending to ancient truths" (Berger 2017, p. xi). In addition to providing new perspectives on old truths, the recreation of these practices in virtual ways provides practical benefits as well, such as drawing in new people, who may feel nervous about walking into an actual church, providing ways of learning from different ecumenical perspectives and giving access to preaching and teaching from all over the world.

Even though there are many benefits to virtual liturgy including the opportunity to experience presence, the remaking of these forms in the digital world still leave out aspects of the physical that are essential to a full practice of liturgy. There are certain practices of liturgy that either cannot be reproduced virtually, such as the sacraments of baptism and communion, or cannot be fully replicated virtually, such as a bodily connection to others and the self. To address the question of the sacraments first, we must admit that it seems impossible to perform the eucharist or baptism virtually, as these both require bodily actions. For baptism, a person must be touched physically by water, although others could be witnesses to the sacrament by watching it online. The eucharist, by definition, is a physical act of eating and drinking that is done by those present, and, especially for some traditions, the act displays a physical presence of grace in the miraculous way that the substance of the bread and the wine turns into the body and blood of Christ during the consecration of the mass, even though its outward qualities remain the same. There have been some attempts to perform it virtually; for example, some churches have mailed out travel size wine and cracker packages ahead of time so that each person can partake in it together while watching the online service. Others have created avatars, a virtual representation of themselves, who digitally take the bread and the wine on social media sites. Whether or not we think that these actions are appropriate, we can observe that these virtual eucharists miss some of the significance of the sacrament: they cannot reproduce a communal corporeal meal that is taken from the same loaves of bread and bottles of wine or grape juice in the same space. This is not to say that the sacraments are defined entirely by their physical actions as it is ultimately the grace given through these sacraments which is most important for believers. However, we must acknowledge the concrete problems of practicing these sacraments virtually, because it is always through the body, through the physical that we access the spiritual realm.

\footnotetext{
13 See Benson's discussion on the importance of repetition in liturgy (Benson 2013, pp. 43-45, 140-41).

14 Thanks to my anonymous reviewer for bringing up this important question.
} 
In aesthetic experience, we found that bodily presence facilitated a deeper knowledge of the self and deeper connection with others and this will be true here in liturgical experiences as well. First, bodily presence in liturgy makes us more truly ourselves. As I am a bodily, communal creature, an experience which fully acknowledges and engages me, will call me to be more who I am designed to be. Like the way art can make us feel at home in our body, liturgy reminds us of the truth of who we are and challenges us to embrace our identity. When I am with a stranger, reflects Marcel, I can feel as if I am also "a stranger to myself" because "I am not really myself when I am with him" (Marcel 2001, p. 205). However, when presence "does really make itself felt, it can refresh my inner being: it reveals me to myself, it makes me more fully myself than I should be if I were not exposed to its impact" (Marcel 2001, p. 205). When I take the bread for communion, it reveals to me that I am an embodied creature dependent both on physical food and spiritual food. Reminding me in a bodily way of my identity, presence in liturgy can refresh my inner being, drawing things out deep inside of me.

Next, to speak to the deeper connections with others in liturgy, we find a greater opportunity for a receiving and giving in an in-person church service. When watching a virtual service, I can feel as if I am only a receiver: the liturgy is in front of me and I take from it what I can. My actions while watching the service do not impact or change the way the liturgy is performed. However, when I am present in my body with the other believers, my actions of singing, praying, raising my hands or kneeling can influence those around me just as those around me in turn inspire me. Like the "concrete us" that can happen in artistic experience, liturgy can bring out a true kind of reciprocal encounter, where "my relationship with you makes a difference to both of us", as Marcel writes (Marcel 2001, p. 181, italics his). Certainly, "collisions" between people happen both virtually and non-virtually, as we will discuss in a moment, but participation in an in-person liturgy can facilitate a greater receiving and giving, where a difference is made on both sides.

Thinking phenomenologically rather than spiritually, we can compare the concrete differences that arise between praying, singing, reading and preaching, virtually and non-virtually. Compare singing along with music online, whether live or recorded, to joining voices who are singing together in the same room: both can bring about a feeling of presence, but the latter can immerse us more fully in the worship, making us feel part of something greater than ourselves. Prayer can have greater depth, for example, when we can lay our hands on the one who is being prayed for. Consider the power of greeting one another in person where we can offer a hug or a handshake rather than only words. Even in preaching, the way a pastor or priest looks out at the congregation while speaking sometimes encourages people to feel as if they are being spoken to directly; "these words were just for me" is a comment often made after a service. While certainly not exhaustive, these simple examples illustrate the deeper connection that we can feel with others during a non-virtual liturgy.

We must remember, however, that even with the priority placed on non-virtual liturgy, an in-person service will not always facilitate bodily presence. There are many times that we may be physically at church, but not engaged spiritually, and thus, not experience true bodily presence. We saw this in aesthetic experience where someone views a sculpture in a park only as an obstacle or someone at a theatre remains inattentive to the play; they are physically there but they cannot engage the art. Relating this to liturgy, Marcel offers the example of a funeral service where we feel disconnected from everyone around us because they are only offering "stereotyped formulas" as condolences. In situations like these, Marcel writes, "We know only too well how easy it is for each of us to find himself with others who are not significantly present at all" (Marcel 1963, p. 67). This kind of interaction with others can be thought of as "collisions" rather than "encounters" because it resembles two objects bumping into one another without any kind of receiving or giving happening between them (Marcel 2001, p. 137). However, everything changes, Marcel writes, when one person acts differently from the others "by a look, an intonation, or by the very quality of his silence, has brought us an undeniable testimony of presence. We were together, and 
this encounter, this co-presence, has left behind a sort of furrow which prolongs it" (Marcel 1963, p. 67). Notice that the change that took place which offered this co-presence was not a change in physical space, but in the way of being in that space by two people.

This reminder does not discount the significance of the physical in sacraments nor the importance of the body in connections with the self and others during liturgy, but, rather, it provides further validation to the idea of humans being undivided wholes, not just bodies and not just minds. Mental engagement, while ignoring our bodies, lacks aspects of a full liturgy; in the same way, being physically there, while our thoughts are elsewhere, will miss some of what liturgy has to offer. Believers often express their desire to offer their whole hearts in worship, and it is in this way, with all of our being, that we seek after communion with others and God.

\section{Conclusions}

In summary, by comparing artistic experience to liturgical experience and by investigating the linguistic and historical roots of liturgy, we can conclude that bodily presence is necessary to have a full and complete liturgy. This is not to make light of the fruit that is produced in virtual liturgical settings; in fact, we should be aware of the digital resources available and how they can reconfigure practices in new ways to reveal spiritual truths. ${ }^{15}$ Virtual liturgy can offer a first step toward an understanding of liturgy, but it will leave us with a longing for more because it cannot fully accomplish the goals for which liturgy was created. Recognizing that liturgy is at heart a bodily and communal practice, our study pushes us to seek out opportunities in liturgy which incorporate a full-body experience, where "our whole being is engaged", as Benson reiterates, for it is there that we can experience the most powerful sense of presence of self, others and God (Benson 2013, p. 153). However, even an experience of a full liturgy will not completely satisfy as it is only an incomplete picture of the invisible, heavenly realm, where believers, with resurrected bodies, will worship in the fullness of Spirit and truth. For now, our access to the presence of the invisible and the divine is dependent on the materiality of liturgy, as Palazzo writes, "[The] very nature of liturgical objects makes it possible for the invisible to become visible and for the divine to be made present" (Palazzo 2010, p. 49, italics mine). Placing the proper weight on the body in liturgy awakens us to the deep experiences of presence that we have available here in our earthly finitude.

Funding: This research received no external funding.

Institutional Review Board Statement: Not applicable

Informed Consent Statement: Not applicable

Data Availability Statement: Not applicable.

Conflicts of Interest: The author declares no conflict of interest

\section{References}

Anderson, Thomas. 2006. A Commentary on Gabriel Marcel's The Mystery of Being. Milwaukee: Marquette University Press. Benson, Bruce Ellis. 2013. Liturgy as a Way of Life: Embodying the Arts in Christian Worship. Grand Rapids: Baker Academic. Berger, Teresa. 2017. @ Worship: Liturgical Practices in Digital Worlds. London: Routledge.

Deleuze, Gilles. 1990. Bergsonism. Translated by Hugh Tomlinson, and Barbara Habberjam. Brooklyn: Zone Books.

Dufrenne, Mikel. 1973. The Phenomenology of Aesthetic Experience. Translated by Edward S. Casey, Albert A. Anderson, Willis Domingo, and Leon Jacobson. Evanston: Northwestern University Press.

Falque, Emmanuel. 2012. The Metamorphosis of Finitude: An Essay on Birth and Resurrection. Translated by George Hughes. New York: Fordham University Press.

Grimshaw, Mark, ed. 2014. The Oxford Handbook on Virtuality. Oxford: Oxford University Press.

Gschwandtner, Christina M. 2020. Welcoming Finitude: Toward a Phenomenology of Orthodox Liturgy. New York: Fordham University Press. Guardini, Romano. 1998. The Spirit of the Liturgy. Translated by Ada Lane. New York: Crossroad Publishing Company.

Heidebrecht, Paul. 2014. Beyond the Cutting Edge?: Yoder, Technology, and the Practices of the Church. Eugene: Pickwick Publications.

15 For a list of digital resources related to liturgy, see (Berger 2017, pp. 134-38). 
Heidegger, Martin. 1976. The Origin of the Work of Art. In Philosophies of Art and Beauty: Selected Readings in Aesthetics from Plato to Heidegger. Edited by Albert Hofstadter and Richard Kuhns. Chicago: University of Chicago Press, pp. 650-708.

Heidegger, Martin. 2008. The Question Concerning Technology. In Basic Writings. New York: HarperCollins, pp. 311-41.

Lacoste, Jean-Yves. 2004. Experience and the Absolute: Disputed Questions on the Humanity of Man. Translated by Mark Raftery-Skehan. New York: Fordham University Press.

Marcel, Gabriel. 1963. The Existential Background of Human Dignity. Cambridge: Harvard University Press.

Marcel, Gabriel. 2001. The Mystery of Being, Volume 1: Reflection and Mystery. Translated by G.S. Fraser. South Bend: St. Augustine's Press.

Marcel, Gabriel. 2002. Creative Fidelity. Translated by Robert Rosthal. New York: Fordham University Press.

Marcel, Gabriel. 2005. Music and Philosophy. Translated by Stephen Maddox, and Robert E. Wood. Milwaukee: Marquette University Press.

McGowan, Andrew. 1999. Ascetic Eucharists: Food and Drink in Early Christian Ritual Meals. Oxford: Clarendon Press.

Merleau-Ponty, Maurice. 1945. Phénoménologie de la Perception. Paris: Gallimard.

Merleau-Ponty, Maurice. 1964. Cézanne's Doubt. In Sense and Non-Sense. Translated by Hubert L. Dreyfus, and Patricia Allen Dreyfus. Evanston: Northwestern University Press, pp. 9-25.

Merleau-Ponty, Maurice. 2004. Eye and Mind. In Maurice Merleau-Ponty: Basic Writings. Edited by Thomas Baldwin. London: Routledge.

Merleau-Ponty, Maurice. 2012. Phenomenology of Perception. Translated by Donald A. Landes. London: Routledge.

Palazzo, Éric. 2008. Performing the Liturgy. In The Cambridge History of Christianity: Early Medieval Christianities c.600-c.1100. Edited by Thomas F.X. Noble and Julia M. H. Smith. Cambridge: Cambridge University Press, pp. 472-88.

Palazzo, Éric. 2010. Art, Liturgy and the Five Sense in the Early Middle Ages. Viator 14: 25-56. [CrossRef]

Parry, Joseph D., and Mark Wrathall. 2011. Introduction. In Art and Phenomenology. London: Routledge, pp. 1-8.

Plato. 1976. The Republic. In Philosophies of Art and Beauty: Selected Readings in Aesthetics from Plato to Heidegger. Edited by Albert Hofstadter and Richard Kuhns. Chicago: University of Chicago Press, pp. 30-45.

Popper, Frank. 2006. From Technological to Virtual Art. Cambridge: The MIT Press.

Price, Charles P., and Louis Weil. 2000. Liturgy for Living. New York: Morehouse Publishing.

Senn, Frank C. 2016. Embodied Liturgy: Lessons in Christian Ritual. Minneapolis: Fortress Press.

Venable, Hannah Lyn. 2021. Madness in Experience and History: Merleau-Ponty's Phenomenology and Foucault's Archaeology. London: Routledge. 